\title{
Methods of assessment of magnesium status in humans: a systematic review
}

\author{
Michał Witkowski, Jane Hubert, Andrzej Mazur \\ INRA, UMR 1019, UNH, CRNH Auvergne, and Clermont Université, Université d'Auvergne, \\ Unité de Nutrition Humaine, BP 10448, Clermont-Ferrand, 63000, France \\ Correspondence: Dr A. Mazur, Unité de Nutrition Humaine, INRA, Theix, 63122 St Genès Champanelle, France \\ <andre.mazur@clermont.inra.fr>
}

\begin{abstract}
To understand humans' requirements for magnesium and the effect of magnesium on health, it is important to identify sensitive and populationspecific biomarkers of magnesium status. Thus, we assessed the effectiveness of different magnesium status biomarkers through a systematic review of published magnesium supplementation and depletion trials in healthy humans. The methods used in this study included a structured search on Ovid MEDLINE, EMBASE (Ovid) and Cochrane databases up to September 2008, followed by the use of formal inclusion/exclusion criteria, data extraction, validity assessment, and meta-analysis. A total of 20 potential biomarkers of magnesium status were assessed from 21 included publications. The majority of studies included were magnesium supplementation studies. Fewer magnesium depletion studies were identified. Available data analysis suggests that serum/plasma magnesium concentration, red blood cell (RBC) concentration and urinary magnesium excretion responded to dietary manipulation. For other biomarkers with available data, it was not possible to draw any conclusions about their usefulness as magnesium status biomarkers. The lack of data prevented detailed subgroup analysis. In conclusion, although limited data were available, serum/plasma magnesium concentration, RBC magnesium concentration and urinary magnesium excretion appear to be useful biomarkers of magnesium status in the general population. Further high-quality studies are needed to assess the effectiveness of existing and newly developed biomarkers, especially in populations that are vulnerable to magnesium deficiency.
\end{abstract}

Key words: magnesium, status, systematic review

Magnesium $\left(\mathrm{Mg}^{2+}\right)$ is the second most abundant cation within the cell. Magnesium plays an essential role in a wide range of fundamental biochemical reactions and cellular functions, including cell cycle, channel regulation, membrane and nucleic acid stability and is a cofactor for hundreds of enzymes [1]. Therefore, it is not surprising that many clinical disorders are associated with magnesium deficiency [2, 3]. Recommendations for magnesium intake are pro-

This manuscript does not necessarily reflect the views of the Commission of the European Communities and in no way anticipates their future policy in this area. vided in the "Dietary Reference Intakes (DRIs)" [4] and in the "Apports nutritionnels conseillés pour la population française (ANC)" [5]. The magnesium content of food in the Western countries is consistently decreasing; currently, dietary magnesium in many adults does not meet the recommended intake [6-11]. This low magnesium intake leads to an increased risk of latent magnesium deficiency, which is difficult to diagnose. It is generally accepted that assessments of magnesium status are problematic [12, 13]. The assessment difficulty results from the distribution of magnesium in the body. About half of the total body magnesium is in the bone and 
the other half is in the soft tissues. Extracellular magnesium accounts for only about 1 percent of total body magnesium. Therefore, the measurement of blood plasma/serum magnesium does not exactly reflect its intracellular level. In healthy subjects, there is a balance between intestinal magnesium absorption and urinary excretion with the latter being of greater importance. Urinary excretion increases when magnesium intake is in excess, whereas the increased kidney reabsorption conserves magnesium in the case of magnesium deprivation. Therefore, urine magnesium reflects magnesium intake and can provide information on an individual's magnesium status. However, factors affecting kidney filtration, such as diabetes, diuretics, and renal dialysis, strongly influence urinary magnesium, limiting its value in several pathophysiological conditions. Homeostasis of magnesium is mainly maintained via bone stores. Approximately one third of magnesium in bone is freely exchangeable and acts as a reserve for maintaining extracellular magnesium concentrations [13]. For these magnesium metabolism-related evidences, extensive research has been conducted on the evaluation of magnesium in a variety of blood cells and on techniques measuring magnesium concentrations in tissues. Recently published reviews [12, 13] provide an extensive update on the assessment of magnesium status.

The aim of this systematic review is to assess the usefulness of magnesium status biomarkers in healthy humans to determine which biomarkers appropriately reflect changes in magnesium status in response to supplementation or depletion. The methodology of this review is based on the standard methodology developed for the set of reviews within the Eurreca project (EURopean micronutrient RECommendations Aligned) (14) and also related to other minerals [15-18].

\section{Methods}

An abbreviated version of the methodology used in this review is provided below with differences from the main methodology noted [14].

\section{Study selection}

To be included, a study needed to meet all of the following criteria: 1) an intervention study in humans (including supplementation and/or depletion studies) with no restrictions in study design, including randomised controlled trials (RCTs), controlled clinical trials (CCTs), and before-andafter studies (B/A); 2) report the magnesium status in humans at baseline and after supplementation or depletion; 3) report the daily dose of the supplement and involve magnesium supplementation with magnesium salts that are considered bioavailable; and 4) involve healthy participants who had not recently used mineral or vitamin supplements.

Study inclusion was not limited by the age of the participants and included studies of infants through the elderly. Studies were excluded if they included subjects receiving concomitant therapy for chronic illnesses, nutritional deficiencies other than magnesium, or if the studies' subjects had a condition known to affect magnesium metabolism, such as diabetes, severe kidney diseases, renal dialysis, or alcoholism. Studies were excluded if suitable baseline data were unavailable, if information on the statistical variance of the data was not accessible, and if methods for the status assessment were not found.

\section{Data collection}

We searched Ovid MEDLINE (www.ovid.com), EMBASE (Ovid; www.ovid.com), and the Cochrane Library CENTRAL (www.thecochranelibrary.com) databases from inception to September 2008 for magnesium intervention studies using text terms with appropriate truncation and relevant indexing terms. The general structure of the search was "magnesium" and "intervention OR supplementation OR depletion" and "humans."

Titles and abstracts were screened for inclusion by a single reviewer. The full text of all articles collected was screened for inclusion by using an inclusion and exclusion form by two independent reviewers. Data for each included study were extracted into an Access (Microsoft Corp, Redmond, WA) database file by a single reviewer. In unclear cases, studies were discussed with the review team before beginning full data extraction, and, in some cases, study authors were contacted for clarification. When necessary, units of measurement were converted to a standard form to facilitate comparison across studies. Data extraction and synthesis for primary and 
secondary measures of interest were undertaken as discussed in the methodology article [14]. To claim whether a biomarker was useful, the following terms indicate the conditions needed to be met: "yes", forest plot showed a significant effect $(p<0.05)$ based on $\geq 3$ studies and $\geq 50$ participants between the intervention and control arms; "unclear but likely to be useful" forest plot showed a significant effect $(p<0.05)$, but the result was based on two studies; "unclear", insufficient data were available.

\section{Results}

The flow diagram for this review is shown in figure 1. Of the 1,298 titles and abstracts screened after electronic and bibliographic searches, 66 appeared potentially relevant and were collected as full-text articles to be assessed for inclusion. At this stage, studies were excluded for a variety of reasons, including unsuitable study designs, such as nonhuman studies, single-case studies, studies not involving magnesium supplementation or depletion, studies without magnesium status measurements, studies on patients with pathologies known to affect magnesium status, and/or studies on patients receiving medication likely to affect magnesium status.

After analysis of the 66 potentially relevant full-text articles, twenty-seven studies (reported in 21 publications) fulfilled all of the inclusion criteria, and details of the included study characteristics are shown in table 1. Studies were excluded if the type of magnesium supplement was not stated, the study design involved multinutrient supplementation, the study did not report baseline and/or subsequent magnesium status, no minimal dose was provided, no control group was studied, a short-term study was performed (e.g., only $24 \mathrm{~h}$ supplementation), or different population groups were used as supplemented and controls. Studies with altered data also resulted in exclusion. However, the majority of exclusion was due to imprecise data (results presentation or no methodology of status assessment) and for lack of magnesium status assessment (figure 1). A total of 20 potential biomarkers of magnesium status were assessed within the 27 included studies from 21 articles. The characteristics of the studies included in the analysis are presented in table 1 . The quality of the included studies varied; 12 RCTs were included in the review, but the method of randomisation was only stated in three studies. The remaining studies included CCT and B/A studies. Methods for checking compliance were reported in only 11 studies. The numbers and reasons for dropouts were reported in eight studies. Full information pertaining to the quality assessment of each study is shown in table 2.

Among the identified biomarkers, only serum magnesium, plasma magnesium, RBC magnesium, and urinary magnesium excretion/ $24 \mathrm{~h}$ were reported in more than three studies with a total of more than 50 studied subjects; therefore, it was reliable to evaluate the effectiveness of these biomarkers. Ionised magnesium in serum, plasma or blood was reported in two, one and two studies, respectively. When combined, there were five studies on plasma/serum/blood ionised magnesium with 51 subjects (figure 1, table 3). Saliva magnesium was evaluated in a three-arm supplementation study with 36 included subjects from one publication (table 3). Studies of other markers were limited to one or two studies and, therefore, were not eligible to allow us to decide whether they were effective markers of magnesium status (table 3).

\section{Serum and plasma total magnesium concentration}

A large proportion of the studies included in this review measured serum (15 studies) or plasma (7 studies) magnesium concentration. All of the supplementation and depletion studies measuring serum and plasma magnesium were combined for statistical analyses. Serum/plasma magnesium concentration was investigated as a marker of magnesium status in 18 supplementation studies involving 275 participants and four depletion studies involving 47 participants. Combining data from the depletion and supplementation studies (322 subjects), primary analysis revealed an overall significant $(\mathrm{p}<0.02)$ response of serum/plasma magnesium concentration to magnesium intake [weighted mean difference (WMD): $0.03 \mathrm{mmol} / \mathrm{L}$; 95\% CI: 0.01, 0.06; $I^{2}$ 96\%]. However, the depletion studies did not detect changes in this parameter (table 3). This biomarker was affected by magnesium supplementation (figure 2). 


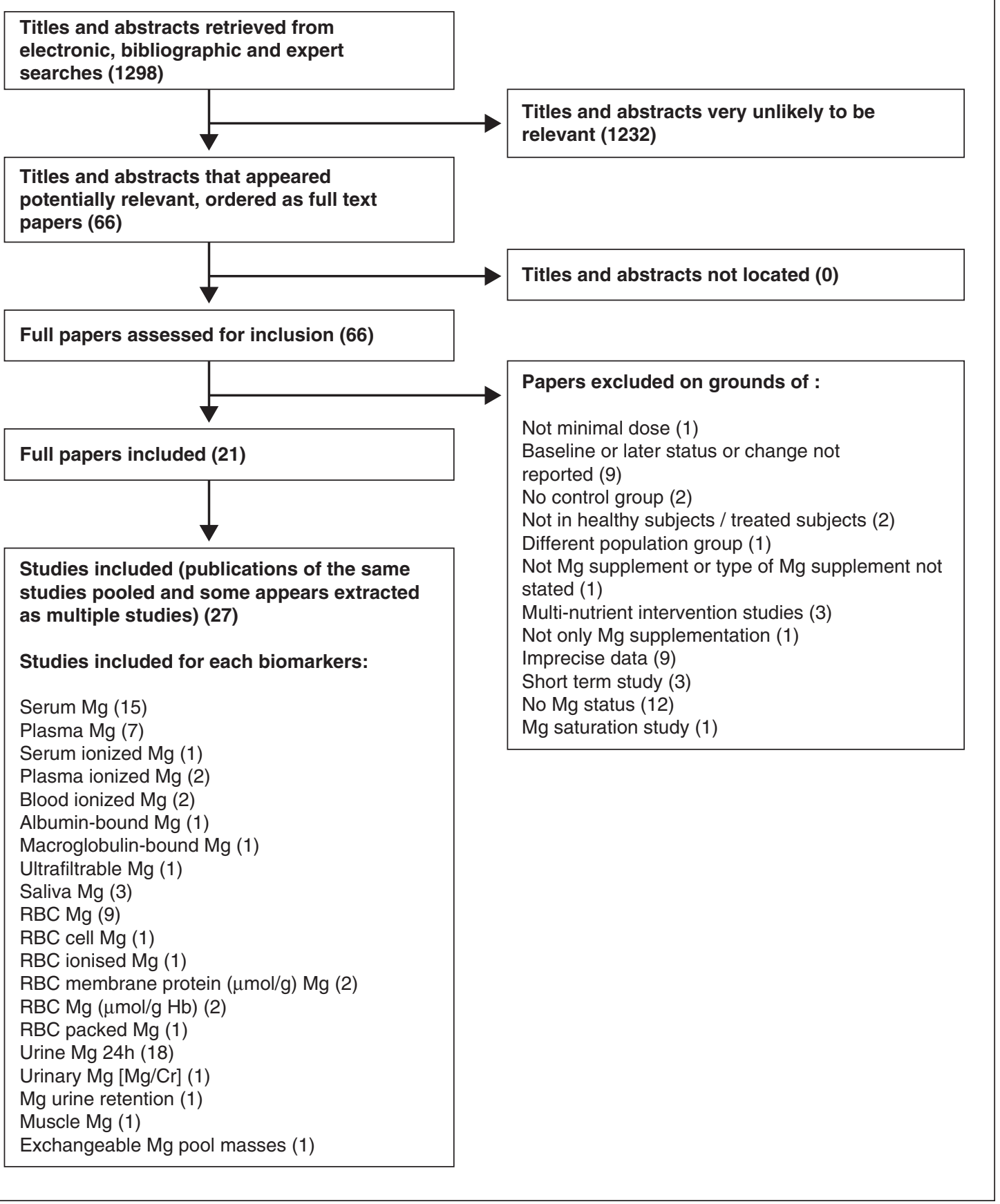

Figure 1. Flow diagram for systematic review of biomarkers of magnesium status. Numbers are in parentheses. 


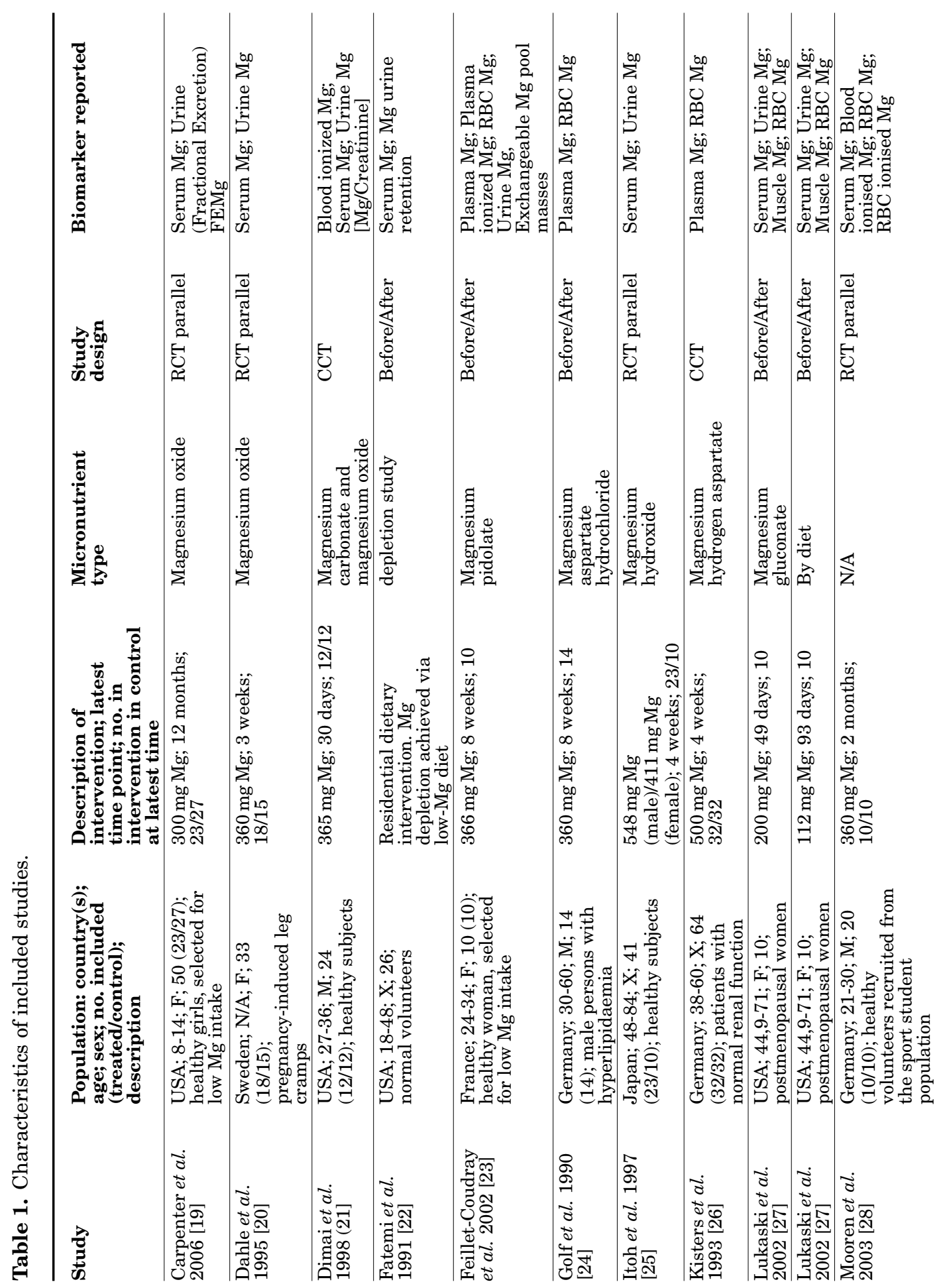




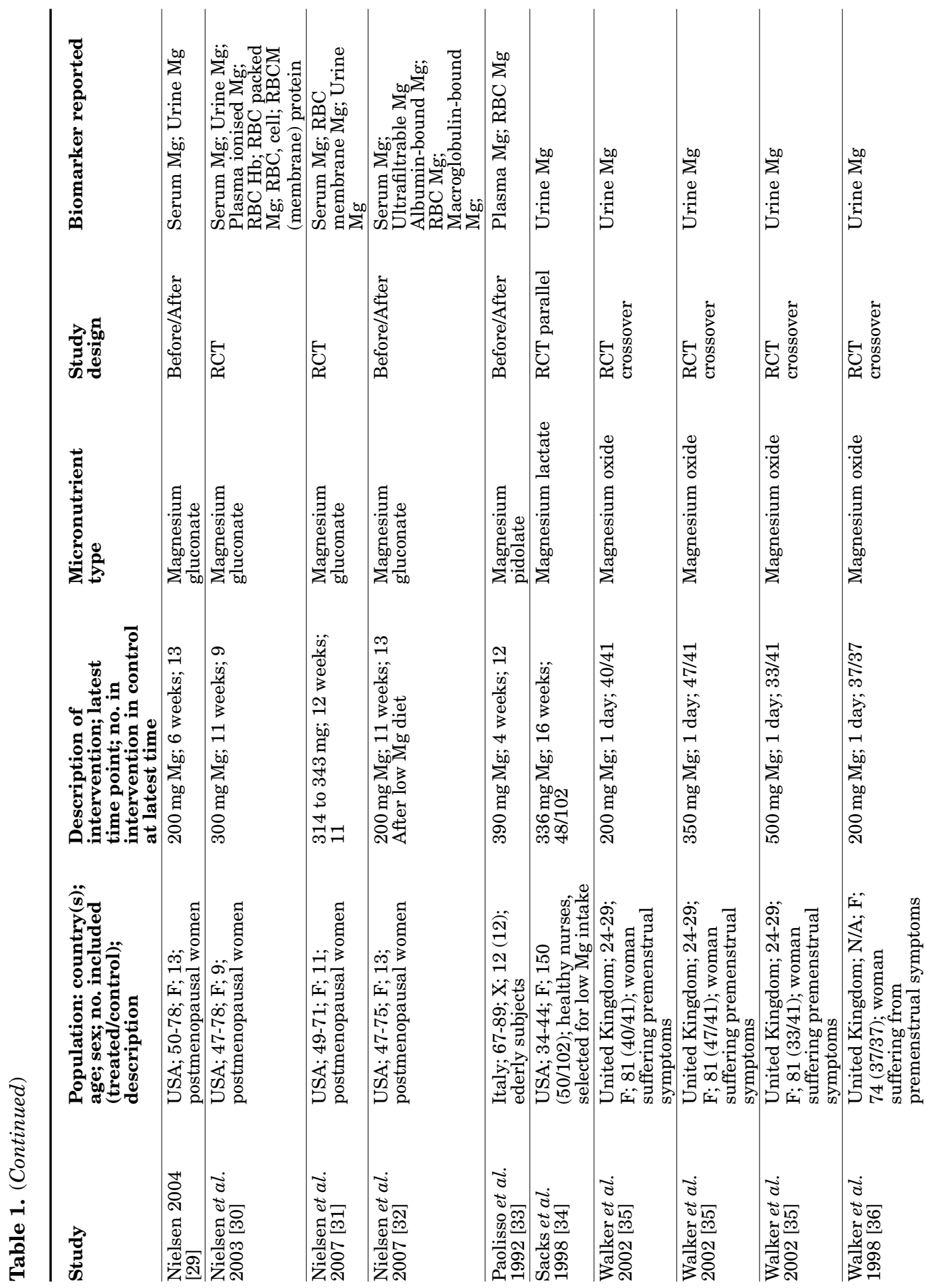




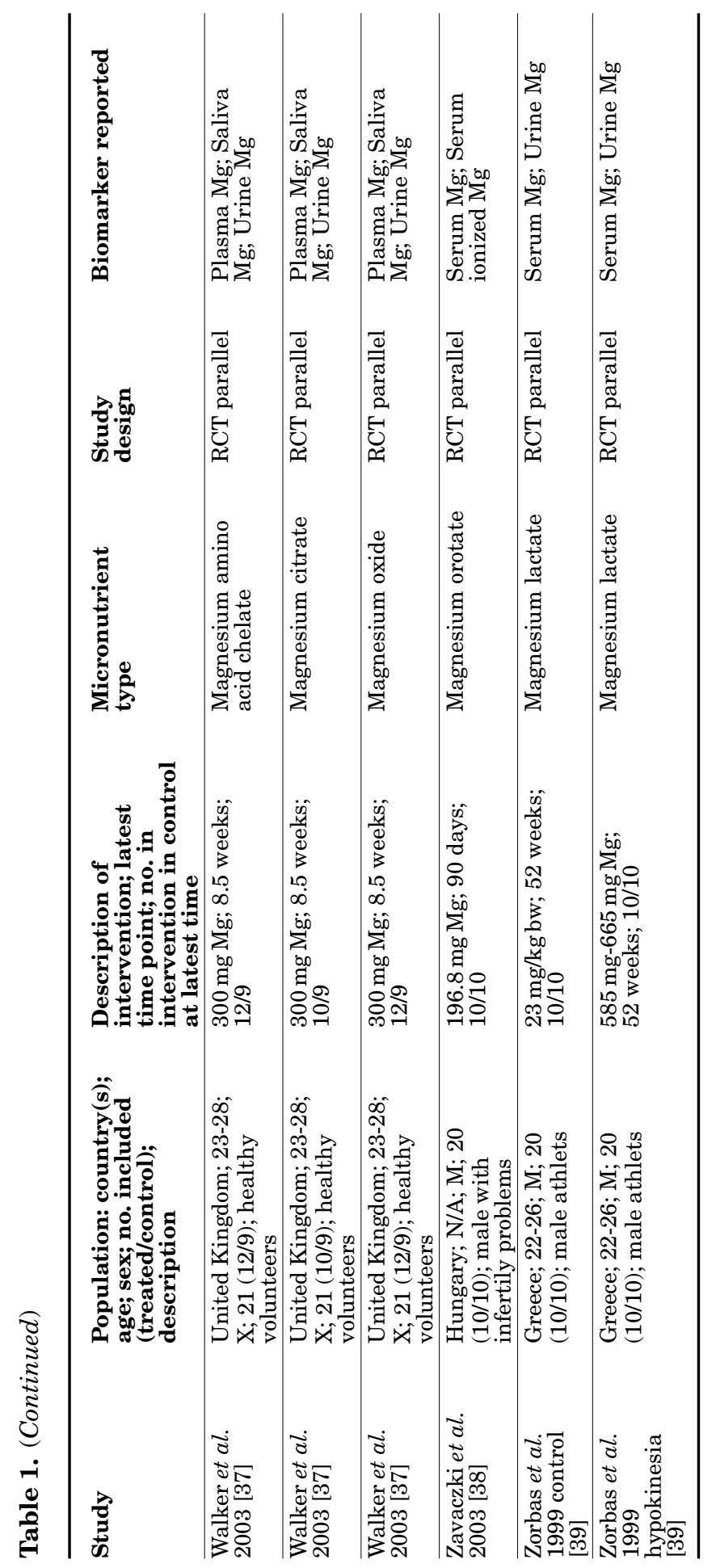




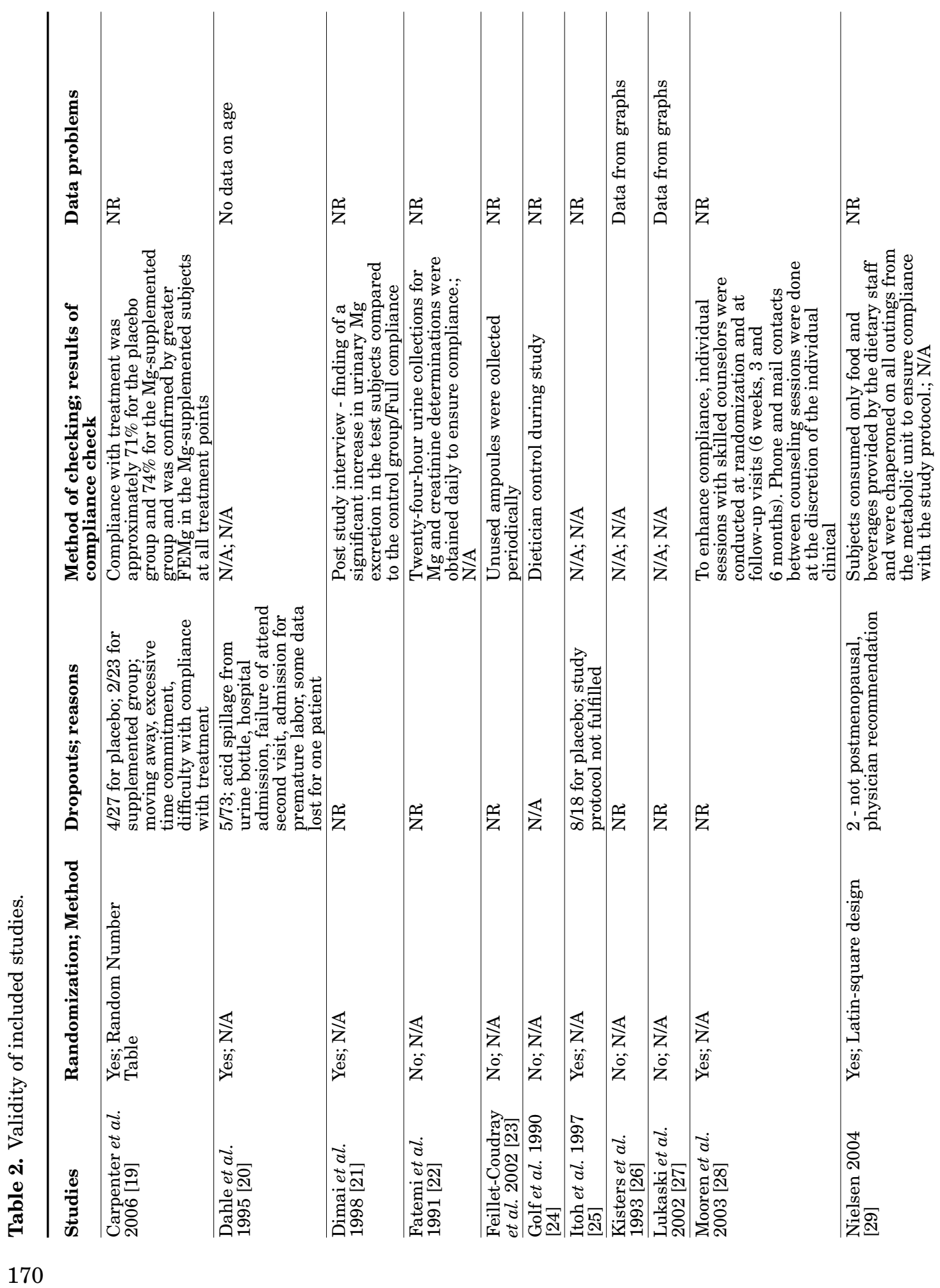




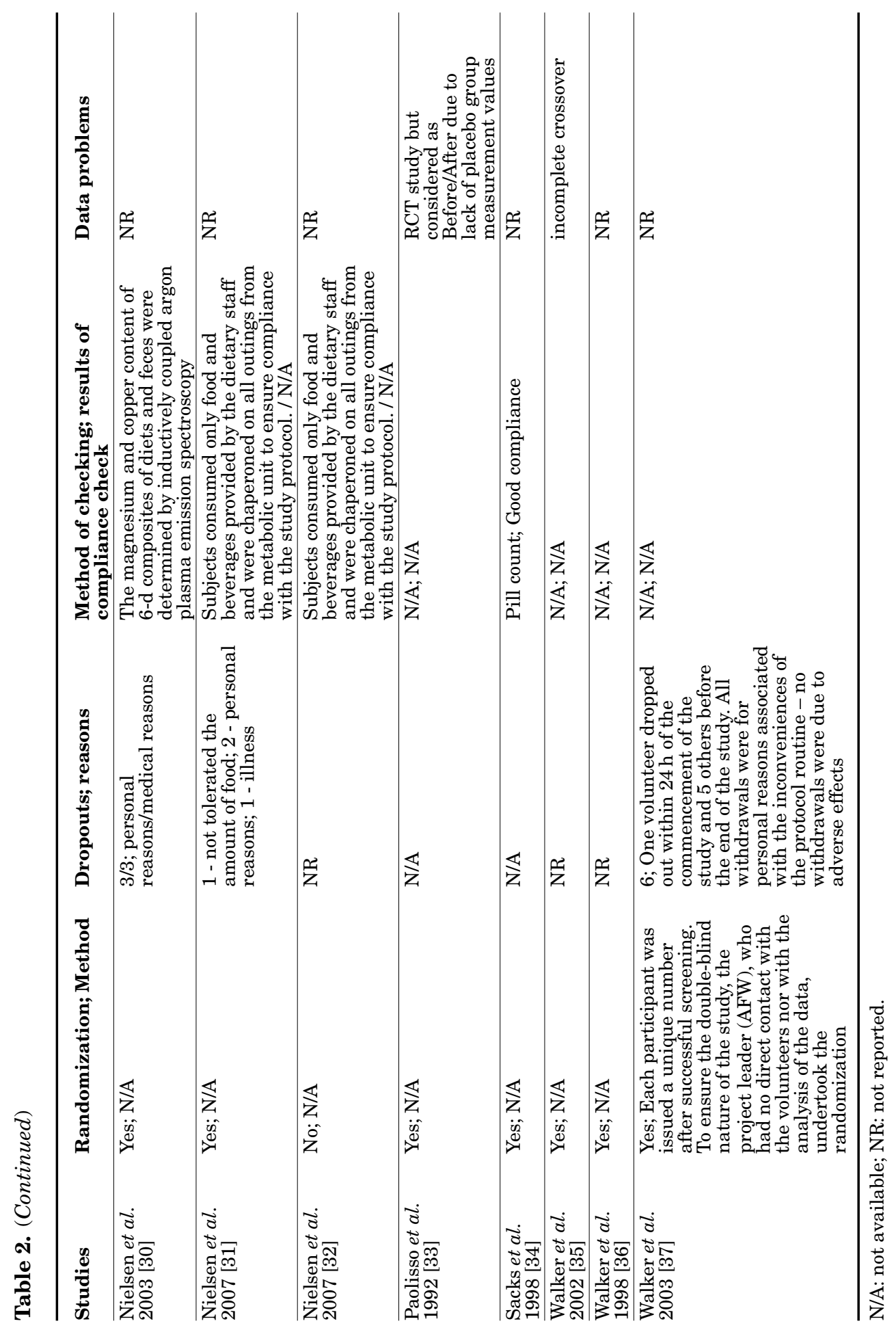


Table 3. Primary outcome data for all biomarkers.

\begin{tabular}{|c|c|c|c|c|}
\hline $\begin{array}{l}\text { Analysis (study type) and } \\
\text { included studies }\end{array}$ & $\begin{array}{l}\text { No. of studies } \\
\text { (no. of included } \\
\text { participants) }\end{array}$ & $\begin{array}{l}\text { Pooled effect size, } \\
\text { WMD }(95 \% \text { CI })\end{array}$ & $\mathbf{I}^{2}$ & $\begin{array}{l}\text { Appears } \\
\text { effective as } \\
\text { a biomarker? }\end{array}$ \\
\hline Plasma/serum Mg (mmol/L) & $22(322)$ & $0.03[0.01,0.06]$ & 96 & Yes \\
\hline $\begin{array}{l}\text { Plasma/serum/blood ionised } \mathrm{Mg} \\
(\mathrm{mmol} / \mathrm{L})\end{array}$ & $5(51)$ & $0.02[-0.02,0.06]$ & 95 & No \\
\hline $\mathrm{RBC} \mathrm{Mg} \mathrm{(mmol/L)}$ & $9(130)$ & $0.16[0.09,0.2]$ & 85 & Yes \\
\hline Urinary $\mathrm{Mg}(\mathrm{mmol} / 24 \mathrm{~h})$ & $18(363)$ & $1.82[1.29,2.36]$ & 93 & Yes \\
\hline Saliva $\mathrm{Mg}(\mathrm{mmol} / \mathrm{L})$ & $3(34)$ & $-0.03[-0.09,0.03]$ & 0 & Unclear \\
\hline Albumin bound $\mathrm{Mg}(\mathrm{mmol} / \mathrm{L})$ & $1(13)$ & $-0.02[-0.04,0.00]$ & - & Unclear \\
\hline FEMg $(\%)$ & $1(23)$ & $0.50[-1.55,2.55]$ & - & Unclear \\
\hline $\begin{array}{l}\text { Macroglobulin-bound Mg } \\
(\mathrm{mmol} / \mathrm{L})\end{array}$ & $1(13)$ & $-0.03[-0.05,-0.01]$ & - & Unclear \\
\hline $\mathrm{Mg}$ urine retention $(\%)$ & $1(16)$ & $51[48.23,53.77]$ & - & Unclear \\
\hline Muscle Mg (mmol/100g dw) & $1(10)$ & $5.50[2.70,8.30]$ & - & Unclear \\
\hline RBC cell $\left(\mu \mathrm{mol} / 10^{6}\right)$ & $1(9)$ & $0.01[0.00,0.02]$ & - & Unclear \\
\hline$\underline{\mathrm{RBC} \text { ionised } \mathrm{Mg}(\mathrm{mmol} / \mathrm{L})}$ & $1(20)$ & $0.05[-0.22,0.32]$ & - & Unclear \\
\hline $\mathrm{RBC} \mathrm{Mg}(\mu \mathrm{mol} / \mathrm{g} \mathrm{Hb})$ & $2(19)$ & $0.50[0.14,0.86]$ & 80 & Unclear \\
\hline RBC packed $\mathrm{Mg}(\mathrm{mmol} / \mathrm{L})$ & $1(9)$ & $0.11[0.10,0.12]$ & - & Unclear \\
\hline $\begin{array}{l}\text { RBC membrane protein } \\
(\mu \mathrm{mol} / \mathrm{g})\end{array}$ & $2(20)$ & $0.16[0.14,0.18]$ & 0 & Unclear \\
\hline Ultrafiltrable $\mathrm{Mg}(\mathrm{mmol} / \mathrm{L})$ & $1(13)$ & $0.00[-0.02,0.02]$ & - & Unclear \\
\hline Urinary $\mathrm{Mg}$ (mmol/g creatinine) & $1(13)$ & $0.17[0.15,0.19]$ & - & Unclear \\
\hline
\end{tabular}

A summary of the population subgroup analysis of the effect of magnesium supplementation and depletion on serum/plasma magnesium concentration is given in the table 4 . Because of the publications available, the data included in this analysis were mostly collected from studies in adults.

\section{Serum, plasma and blood ionised magnesium concentration}

Two studies included in this review measured plasma, one measured serum and two measured plasma ionised magnesium concentrations. These five studies were combined for statistical analyses and included $3 \mathrm{RCT}, 1 \mathrm{CCT}$, and 1B/A, with four studies involving supplementation and one involving depletion. The retained studies involved 51 subjects. Neither primary analysis nor any individual study suggested a response of this biomarker to changes in magnesium intake. The primary analysis did not reveal a significant response to changes in dietary magnesium intake (WMD: $0.02 \mathrm{mmol} / \mathrm{L}$; 95\% CI: -0.02, 0.06; $I^{2} 95 \%$ ) (table 3).

\section{Other serum and plasma biomarkers}

Only one study on a limited number of subjects was available for each of the other serum and plasma biomarkers: serum ultrafiltrable magnesium, albumin-bound magnesium, and macroglobulin-bound magnesium [31, 32] (figure 1, table 3). Consequently, it was not possible to draw any conclusions regarding the usefulness of these biomarkers.

\section{RBC magnesium concentration}

Combining data from three depletion and six supplementation studies (on 130 subjects), primary analysis revealed a significant overall $(\mathrm{p}<0.0001)$ response of erythrocyte magnesium concentration to magnesium intake (WMD: $0.16 \mathrm{mmol} / \mathrm{L} ; 95 \%$ CI: $0.09,0.22 ; I^{2} 85 \%$ ) (figure 3 ).

In some of the selected studies, RBC magnesium was expressed by cell or haemoglobin, and also RBC membrane magnesium or free intracellular ionised magnesium concentrations were measured [28, 30, 32]. The results from these isolated studies were not combined for further analyses with the majority of available studies 


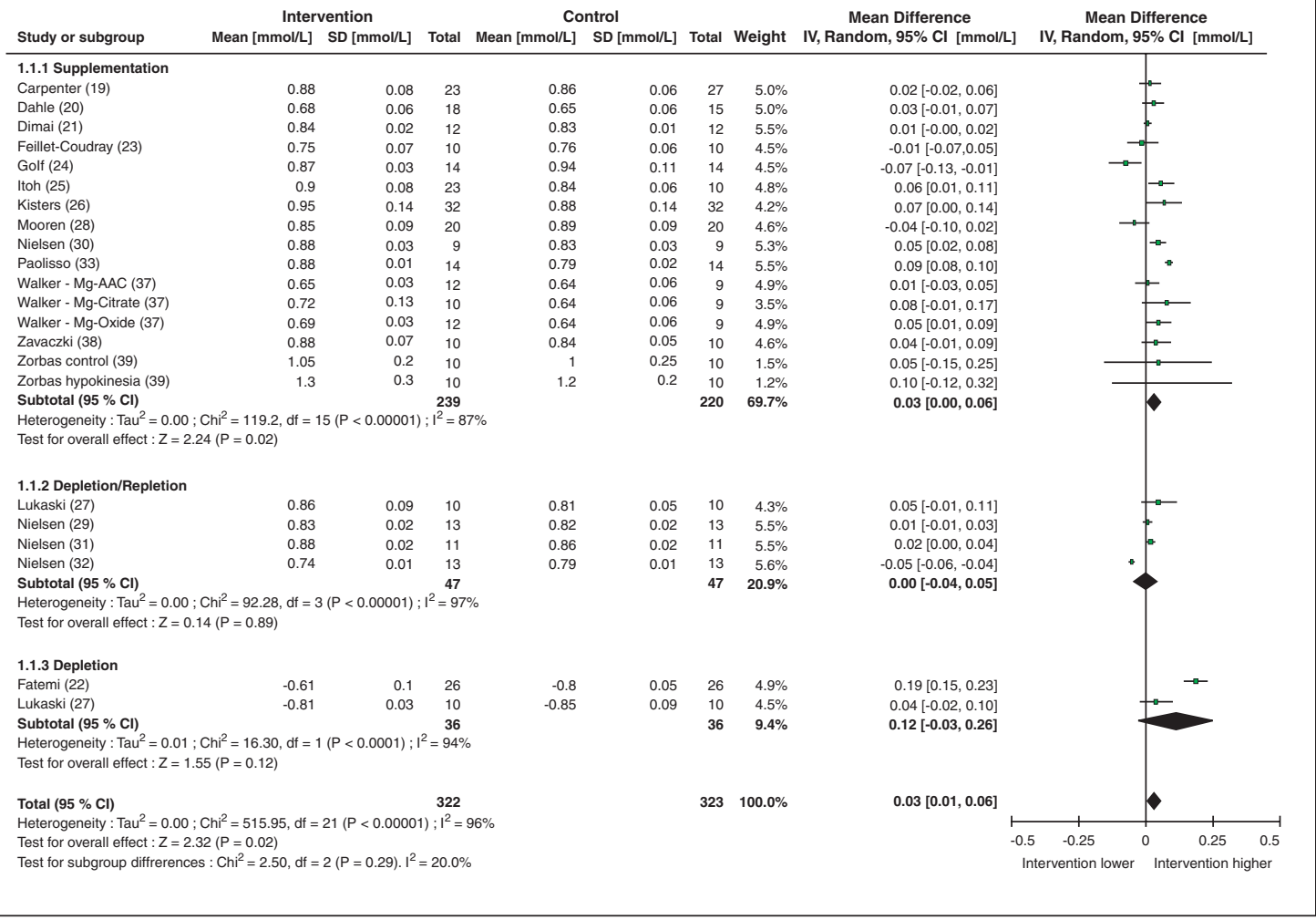

Figure 2. Serum/plasma magnesium ( $\mathrm{mmol} / \mathrm{L})$ response to magnesium supplementation or depletion.

that reported $\mathrm{RBC}$ magnesium concentrations expressed by RBC volume.

\section{Urinary magnesium}

Combining data from $14 \mathrm{RCT}$ and $5 \mathrm{~B} / \mathrm{A}$ studies (table 3), which included four depletion and 15 supplementation studies, primary analysis revealed an overall significant $(\mathrm{p}<0.00001)$ response of urinary magnesium excretion to dietary magnesium intake (WMD: $1.82 \mathrm{mmol} / 24 \mathrm{~h}$; 95\% CI: 1.29, 2.36; $I^{2}$ 93\%) (figure 4).

Data from one CCT study expressed urinary magnesium as magnesium/creatinine [21] and from one study calculating urine fractional excretion of magnesium (FEMg) (a parallel RCT with magnesium supplemented girls) [19] have not been incorporated into the statistical analysis because of the difference in the calculation method used and expression of the results; the majority of studies evaluating 24-h Mg excretion. However, it was not possible to draw any firm conclusions about the effectiveness of these two last parameters, which were considered separately because of the insufficient number of subjects and available studies (table 3).

A summary of the population subgroup analysis of the response of urine magnesium concentration to magnesium supplementation and depletion is provided in the table 4 . The data included in this analysis were mostly collected from studies in adults. In adults, urinary magnesium appears to be an effective biomarker.

\section{Saliva magnesium}

One RCT parallel supplementation study with three different magnesium salts, which included 12 participants per arm, assessed saliva magnesium [37]. There were not enough studies of this biomarker to draw any conclusions about its usefulness (table 3). 
Table 4. Secondary outcome data for plasma/serum and urinary biomarkers.

\begin{tabular}{|c|c|c|c|c|}
\hline $\begin{array}{l}\text { Analysis (study type) and } \\
\text { included studies }\end{array}$ & $\begin{array}{l}\text { No. of studies } \\
\text { (no. of included } \\
\text { participants) }\end{array}$ & $\begin{array}{l}\text { Pooled effect size, } \\
\text { WMD (95\% CI) }\end{array}$ & $\mathbf{I}^{2}$ & $\begin{array}{l}\text { Appears } \\
\text { effective as } \\
\text { a biomarker? }\end{array}$ \\
\hline $\begin{array}{l}\text { Plasma/serum } \mathrm{Mg} \text { - females } \\
(\mathrm{mmol} / \mathrm{L})\end{array}$ & $8(107)$ & $0.01[-0.02,0.05]$ & 95 & No \\
\hline $\begin{array}{l}\text { Plasma/serum } \mathrm{Mg} \text { - mixed } \\
(\mathrm{mmol} / \mathrm{L})\end{array}$ & $7(129)$ & $0.08[0.04,0.12]$ & 85 & Yes \\
\hline $\begin{array}{l}\text { Plasma/serum } \mathrm{Mg} \text { - males } \\
(\mathrm{mmol} / \mathrm{L})\end{array}$ & $6(76)$ & $-0.01[-0.04,0.03]$ & 57 & No \\
\hline $\begin{array}{l}\text { Plasma/serum } \mathrm{Mg}- \\
\text { postmenopausal women } \\
\text { (mmol/L) }\end{array}$ & $5(56)$ & $0.01[-0.03,0.05]$ & 97 & No \\
\hline $\begin{array}{l}\text { Plasma/serum } \mathrm{Mg} \text { - adults } \\
(\mathrm{mmol} / \mathrm{L})\end{array}$ & $13(209)$ & $0.04[0.00,0.07]$ & 86 & No \\
\hline $\begin{array}{l}\text { Urinary } \mathrm{Mg} \text { - females } \\
(\mathrm{mmol} / 24 \mathrm{~h})\end{array}$ & $14(310)$ & $1.65[1.18,2.11]$ & 85 & Yes \\
\hline Urinary $\mathrm{Mg}-$ mixed $(\mathrm{mmol} / 24 \mathrm{~h})$ & $4(57)$ & $1.54[0.98,2.10]$ & 36 & Yes \\
\hline $\begin{array}{l}\text { Urinary } \mathrm{Mg} \text { - postmenopausal } \\
\text { women }(\mathrm{mmol} / 24 \mathrm{~h})\end{array}$ & $4(43)$ & $2.31[1.76,2.85]$ & 85 & Unclear \\
\hline Urinary $\mathrm{Mg}$ - adults $(\mathrm{mmol} / 24 \mathrm{~h})$ & $13(310)$ & $1.69[0.84,2.54]$ & 94 & Yes \\
\hline
\end{tabular}

\section{Other biomarkers}

Urinary magnesium retention was only studied in one B/A study [22] of 26 subjects.

Muscle magnesium was only evaluated in one B/A study on ten magnesium-supplemented postmenopausal women [27]. Exchangeable magnesium pool masses were only evaluated in one B/A study on ten magnesium-supplemented young women [23]. Consequently, it was not possible to draw any conclusions about the usefulness of these biomarkers (table 3).

\section{Discussion}

A total of 21 publications with RCTs, CCTs and $\mathrm{B} / \mathrm{A}$ studies were included in this review. The majority of studies included were magnesium

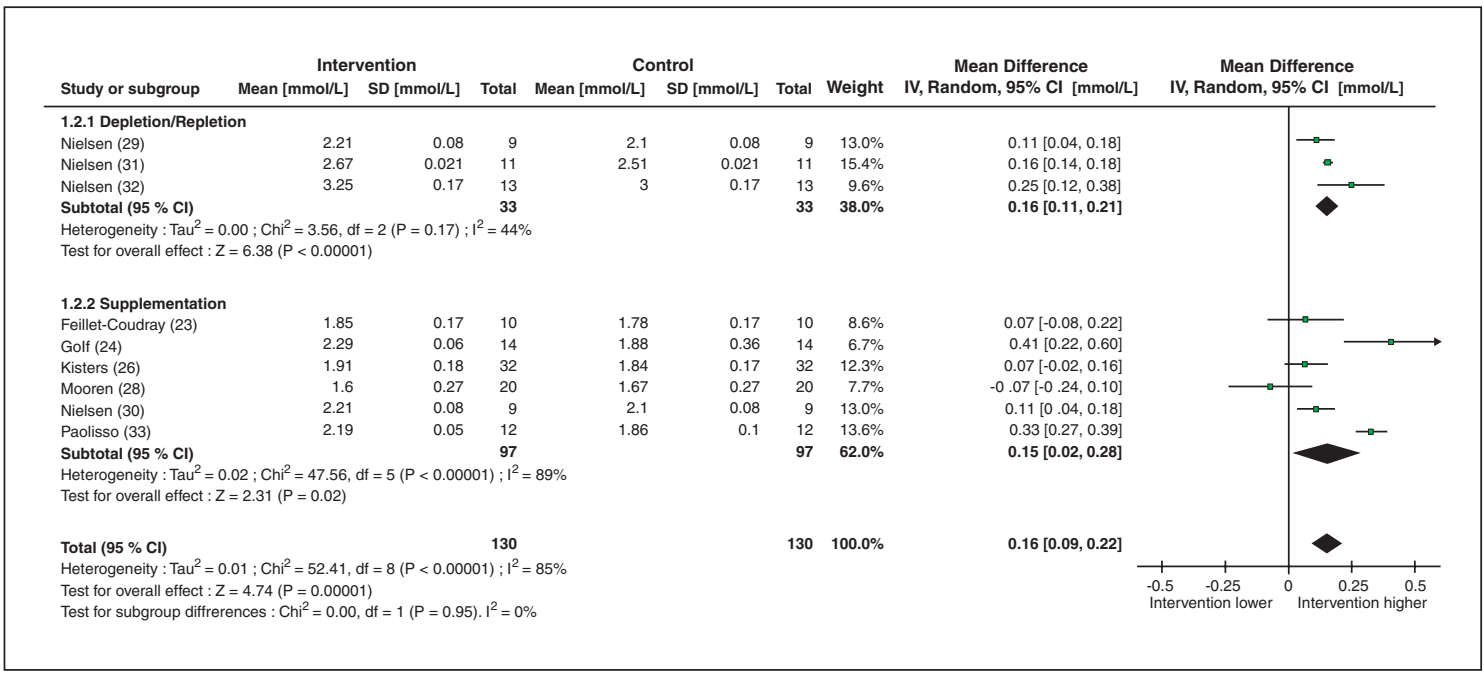

Figure 3. RBC magnesium ( $\mathrm{mmol} / \mathrm{L}$ ) response to magnesium supplementation or depletion. Arrowheads indicate direction of response when unable to represent data on most appropriate scale. 


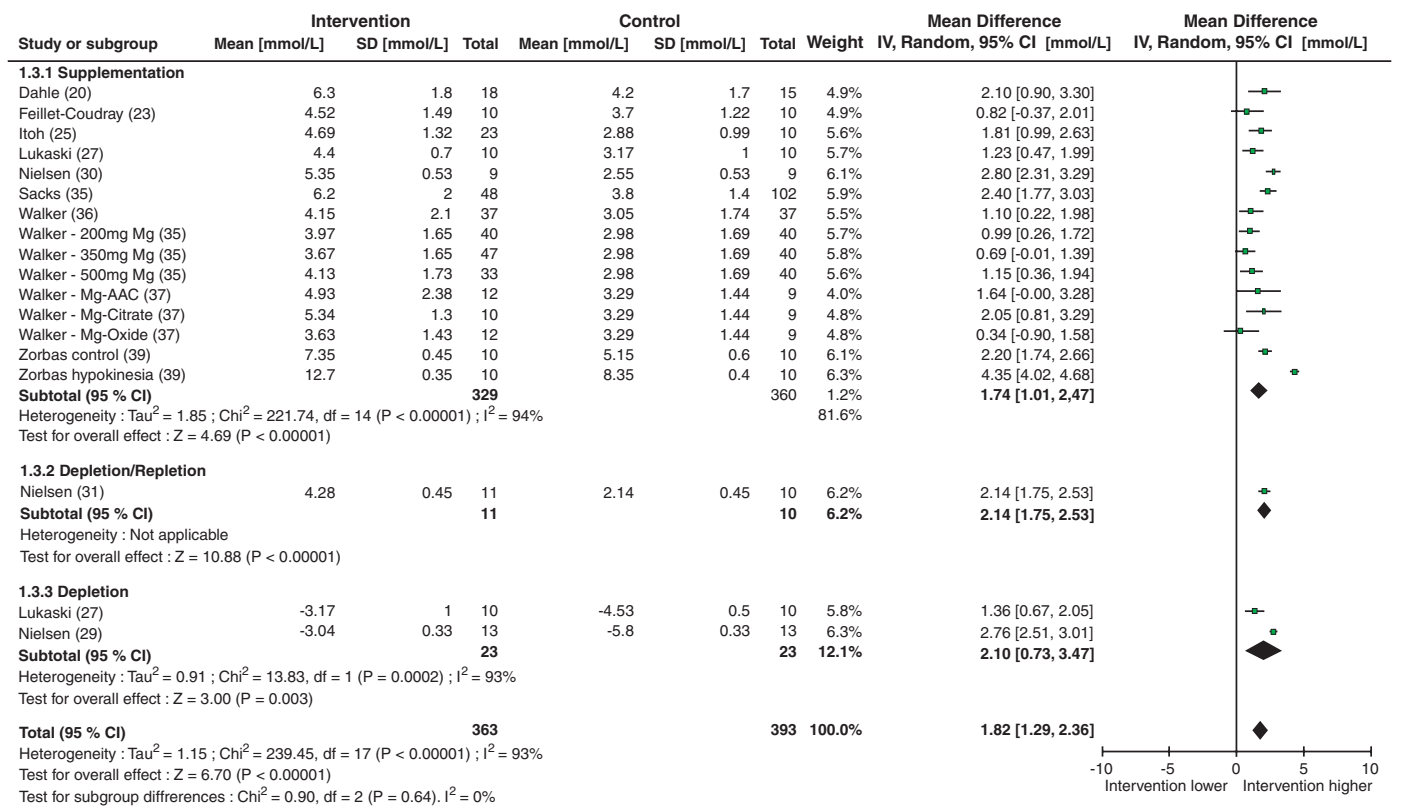

Figure 4. Urinary magnesium $(\mathrm{mmol} / 24 \mathrm{~h})$ response to magnesium supplementation or depletion.

supplementation studies. Fewer magnesium depletion studies were identified with lower total numbers of participants than supplementation studies. A significant proportion of the analyses conducted for individual biomarkers did not meet the minimum criteria for determining their usefulness, i.e., they had $<3$ studies or $<50$ participants contributing data to the meta-analysis according to the methodology used [14]. However, it should be stressed that several of these parameters arise from the application of different methodologies for the equivalent parameters, thereby leading to different expression of the results (e.g., analyses on $\mathrm{RBC}$ and urine). With regard to the limited number of these studies, it was not possible to conclude on the potential usefulness of several of these particular assessments. Among the identified biomarkers, only serum magnesium, plasma magnesium, RBC magnesium, and urinary magnesium excretion $/ 24 \mathrm{~h}$ were reported in more than three studies with a total of more than 50 studied subjects and thus were reliable for evaluation of biomarker effectiveness. These data were combined as serum/plasma because, frequently, total serum and plasma magnesium were alternatively measured. Finally, we concluded that serum/plasma magnesium concentration, RBC magnesium concentration, and urinary magnesium excretion responded to dietary manipulation. Consequently, these parameters appear to be useful biomarkers of magnesium status in the general population.

For the other potential biomarkers, special attention was paid to free extracellular ionised magnesium. This fraction of magnesium is generally considered as a more specific marker of magnesium status than total plasma or serum magnesium [12]. Only five studies of this biomarker were eligible according to the review criteria. However, the analyses in these studies were performed on serum, plasma, or blood samples. Also, various equipment (AVL or NOVA8+) were used in the retained studies. As previously discussed, significant differences among the ionised magnesium concentration have been obtained with various analysers [40]. Despite these limitations, we aggregated all the available results on plasma, serum and blood because of the low number of relevant studies. Finally, because 
of the available data, it was not possible to conclude if ionised magnesium concentration is likely to be effective or ineffective as biomarkers of magnesium status.

Unfortunately, the studies included in this review on biomarkers of potential interest, i.e., exchangeable pools of magnesium and muscle and saliva magnesium, were only reported by one study, for each of this parameter, with a low number of included subjects. These and other biomarkers of potential interest (bone, platelets, white blood cell magnesium) could also not be analysed because the available studies did not meet sufficient criteria to be included to this review.

Due to the low number of available studies and studies with low number of included subjects, there is not enough information to make a clear decision about magnesium status biomarkers in specific subgroups. The majority of studies have been conducted in adults. After subgrouping, mainly urine magnesium excretion was shown to be significantly modulated by magnesium intake in adults and females (table 4). There was no capacity within the data to conduct subgroup analysis for a range of population groups, especially vulnerable populations, e.g. infants, adolescents, pregnant women, or elderly subjects. In fact, we have identified only one publication for each of following groups: 10-year-old girls [19], pregnant women [20] and elderly subjects [33]. Also, few publications provided an extensive description of the subjects studied. It would be of interest to evaluate the relationship between magnesium status markers and body mass index (BMI). Numerous publications point out the relationship between low magnesium intake and metabolic syndrome, obesity and type 2 diabetes $[8,10,41-48]$. Several studies have reported lower magnesium status in these conditions, and this relationship is currently under debate [49-57]. However, available data did not allowed us to isolate these specific groups for further analyses.

The major limitation for conducting this systematic review is the low number of available studies (preferably RCTs) on healthy subjects. Papers were carefully selected; however, some of selected studies have been conducted on subjects presenting commonly encountered pathophysiological conditions, i.e., pregnancy-induced leg cramps [20], untreated hyperlipidemia [24], premenstrual symptoms [35, 36], male infertility problems [38], intense sport activity [28, 39], hypokinesia [39]. To our knowledge, all of these subjects did not receive medications or supplements other than magnesium. Because only isolated studies are available for these subjects, it was not possible to relate these conditions to the magnesium status.

Furthermore, it was not possible to draw conclusions about potential relations between biomarker responsiveness and type, dose, or length of supplementation. Various magnesium supplements were used in the selected studies: oxide, aspartate, hydroxide, gluconate, pidolate, citrate, lactate, carbonate and amino acid chelate. The duration of supplementation and the dose used varied in these studies; however, a majority of the included studies used 200 to $400 \mathrm{mg}$ magnesium/day. The use of organic magnesium salts in several of the included studies results from the consideration that these salts are more bioavailable than are nonorganic ones [58]. Because of the diversity of supplements, protocols and subjects, we did not attempt to compare their efficiency in our analysis. It is also noteworthy that we have not included studies with magnesium/vitamin B6 supplementation in our review. Magnesium/vitamin B6 is a common magnesium supplement, but a possible interaction exists between these two compounds. Future analysis of the available data on magnesium/vitamin B6 supplementation should be conducted to evaluate the possible benefits of their interaction.

The data included in this review are mainly from supplemented subjects and few data are available from depleted individuals. A prolonged magnesium depletion study with $101 \mathrm{mg}$ of magnesium/day exhibited adverse heart rhythm changes after 78 days of depletion [32]. Consequently, the implementation of depletion studies should be carefully considered from an ethical point of view.

The present review reveals that even if magnesium supplementation is used for a long time, well-designed intervention RCTs in healthy individuals with respect to their physiological and nutritional conditions are scarce. Although this systematic review offers primary outcome data for each biomarker identified, the limited number of studies included and the limited number of subjects in the population subgroups render it impossible to draw conclusions about potential relations between biomarker responsiveness for a range of population groups. Subsequently, further studies should be conducted on the best way to 
evaluate magnesium status in population groups susceptible to magnesium deficiency. In particular, the research should be focused on evaluating intracellular magnesium and body pools of magnesium. It would be of interest to connect these studies with a magnesium balance evaluation [59]. Additionally, it is important to stress that compared to many other minerals, such as selenium, iodine, zinc and copper [15-18], biomarkers for magnesium status are limited to the magnesium measurements in biological fluids, cells and tissues. At present, no indirect biomarkers of magnesium status are identified. The recent progress in identifying genes modulated by magnesium concentration opens interesting perspectives for the research of these biomarkers.

Genetic factors controlling intra- and extracellular Mg levels should be considered in the future research of biomarkers; however, these genetic factors are weakly known. Serum magnesium concentrations have been shown to have a heritable component with heritability estimates of $\sim 30 \%$ [60]. The pioneer study by Henrotte et al. in 1990 [61] pointed out the importance of genetics for plasma and RBC magnesium levels. This finding was confirmed in a mouse animal model selected for low and high RBC magnesium [62]. Recent advances in the fields of genetics and genomics have allowed for substantial progress in this area by identifying new players of magnesium homeostasis regulation [63-65]. Recently published genome-wide meta-analysis of cohorts identified six genomic regions that contained common variants associated with serum magnesium levels [66]. All of the variants were nominally associated with clinically defined hypomagnesaemia. These data from human genetics will initiate a new era in understanding the relationship between genetics, nutrition and diseases in determining magnesium status.

The selection process of the data included in the present review highlighted that the quality of published data are often poor for the purpose of a systematic review on magnesium status. Several publications did not provide sufficient or clear information on the magnesium intake, on the clinical protocol, and on the assay methodology. These issues should be considered when planning projects and publishing results. Well-designed RCTs of sufficient size with varying doses and duration of supplementation and with evaluation of the magnesium intake using a whole-diet profile (e.g., magnesium/calories ratio) are required in various population subgroups. With emerging knowledge of genetic factors determining magnesium status, it will be important in future studies to take into account the genetic background of studied subjects. Ultimately, the results of such studies could contribute to the development of evidence-based dietary recommendations that are better targeted to specific populations.

\section{Acknowledgments}

We want to thank Kate Ashton for her assistance in the literature searching and Edmond Rock for critically reading the manuscript.

\section{Disclosure}

Supported partially by the Commission of the European Communities, specific RTD Programme "Quality of Life and Management of Living Resources," within the 6th Framework Programme (contract no. FP6-036196-2).

EURRECA: EURopean micronutrient RECommendations Aligned.

None of the authors has any conflict of interest to disclose.

\section{References}

1. Romani A. Regulation of magnesium homeostasis and transport in mammalian cells. Arch Biochem Biophys 2007; 458: 90-102.

2. Durlach J. Magnesium in clinical practice. London: John Libbey, 1988.

3. Rayssiguier A, Mazur A, Durlach J, eds. Advances in magnesium research: nutrition and health. London: John Libbey, 2001 (502 p.).

4. Standing Committee on the Scientific Evaluation of Dietary Reference Intakes, Food and Nutrition Board, Institute of Medicine, National Academy of Sciences. Dietary reference intakes for calcium, phosphorus, magnesium, vitamin D, and fluoride. Washington, DC: National Academy Press, 1997.

5. Martin A (coordonnateur). Apports nutritionnels conseillés pour la population française. $3^{\mathrm{e}}$ ed. TEC et DOC, Lavoisier, 2001.

6. Galan P, Preziosi P, Durlach V, Valeix P, Ribas L, Bouzid D, Favier A, Hercberg S. Dietary magnesium 
intake in a French adult population. Magnes Res 1997; 10: 321-8.

7. Pennington JAT. Current dietary intakes of trace elements and minerals. In: Bogden JD, Klevey LM, eds. Clinical nutrition of the essential trace elements and minerals. Totowa, NJ: Humana Press, 2000, p. 49-67.

8. King DE, Mainous 3rd. AG, Geesey ME, Woolson RF. Dietary magnesium and C-reactive protein levels. $J$ Am Coll Nutr 2005; 24: 166-71.

9. Moshfegh A, Goldman JD, Cleveland LE. What we eat in America, NHANES 2001-2002: usual nutrient intakes from food compared to dietary reference intakes.. Totowa, NJ: U.S. Department of Agriculture, Agricultural Research Service, 2005.

10. Bo S, Durazzo M, Guidi S, Carello M, Sacerdote C, Silli B, Rosato R, Cassader M, Gentile L, Pagano G. Dietary magnesium and fiber intakes and inflammatory and metabolic indicators in middle-aged subjects from a population-based cohort. Am J Clin Nutr 2006; 84: 1062-9.

11. Rosanoff A. Rising Ca:Mg intake ratio from food in USA adults: a concern?. Magnes Res 2010; 23: S18193.

12. Arnaud MJ. Update on the assessment of magnesium status. Br J Nutr 2008; 99 (suppl. 3): S24-36.

13. Elin RJ. Assessment of magnesium status for diagnosis and therapy. Magnes Res 2010; 23: 194-8.

14. Hooper L, Ashton K, Harvey LJ, Decsi T, Fairweather-Tait SJ. Assessing potential biomarkers of micronutrient status by using a systematic review methodology: methods. Am J Clin Nutr 2009; 89: 1953S-9S.

15. Ristic-Medic D, Piskackova Z, Hooper L, Ruprich J, Casgrain A, Ashton K, Pavlovic M, Glibetic M. Methods of assessment of iodine status in humans: a systematic review. Am J Clin Nutr 2009; 89: 2052S$69 \mathrm{~S}$

16. Ashton K, Hooper L, Harvey LJ, Hurst R, Casgrain A, Fairweather-Tait SJ. Methods of assessment of selenium status in humans: a systematic review. $\mathrm{Am}$ J Clin Nutr 2009; 89: 2025S-39S.

17. Harvey LJ, Ashton K, Hooper L, Casgrain A, Fairweather-Tait SJ. Methods of assessment of copper status in humans: a systematic review. $A m$ J Clin Nutr 2009; 89: 2009S-24S.

18. Lowe NM, Fekete K, Decsi T. Methods of assessment of zinc status in humans: a systematic review. Am J Clin Nutr 2009; 89: 2040S-51S.

19. Carpenter TO, DeLucia MC, Zhang JH, Bejnerowicz G, Tartamella L, Dziura J, Petersen KF, Befroy D,
Cohen D. A randomized controlled study of effects of dietary magnesium oxide supplementation on bone mineral content in healthy girls. J Clin Endocrinol Metab 2006; 91: 4866-72.

20. Dahle LO, Berg G, Hammar M, Hurtig M, Larsson L. The effect of oral magnesium substitution on pregnancy-induced leg cramps. Am J Obstet Gynecol 1995; 173: 175-80.

21. Dimai HP, Porta S, Wirnsberger G, Lindschinger M, Pamperl I, Dobnig H, Wilders-Truschnig M, Lau KH. Daily oral magnesium supplementation suppresses bone turnover in young adult males. J Clin Endocrinol Metab 1998; 83: 2742-8.

22. Fatemi S, Ryzen E, Flores J, Endres DB, Rude RK. Effect of experimental human magnesium depletion on parathyroid hormone secretion and 1,25dihydroxyvitamin D metabolism. J Clin Endocrinol Metab 1991; 73: 1067-72.

23. Feillet-Coudray C, Coudray C, Tressol JC, Pépin D, Mazur A, Abrams SA, Rayssiguier Y. Exchangeable magnesium pool masses in healthy women: effects of magnesium supplementation. Am J Clin Nutr 2002; 75: 72-8.

24. Golf SW, Riediger H, Matthes S, Kuhn D. Effects of magnesium treatment on hyperlipemia. Magnes Bull 1990; 12: 138-43.

25. Itoh K, Kawasaka T, Nakamura M. The effects of high oral magnesium supplementation on blood pressure, serum lipids and related variables in apparently healthy Japanese subjects. $\mathrm{Br} J \mathrm{Nutr}$ 1997; 78: 737-50.

26. Kisters K, Spieker C, Tepel M, Zidek W. New data about the effects of oral physiological magnesium supplementation on several cardiovascular risk factors (lipids and blood pressure). Magnes Res 1993; 6: 355-60.

27. Lukaski HC, Nielsen FH. Dietary magnesium depletion affects metabolic responses during submaximal exercise in postmenopausal women. $J$ Nutr 2002; 132: 930-5.

28. Mooren FC, Golf SW, Völker K. Effect of magnesium on granulocyte function and on the exercise induced inflammatory response. Magnes Res 2003;16: 49-58.

29. Nielsen FH. The alteration of magnesium, calcium and phosphorus metabolism by dietary magnesium deprivation in postmenopausal women is not affected by dietary boron deprivation. Magnes Res 2004; 17: 197-210.

30. Nielsen FH, Milne DB. Some magnesium status indicators and oxidative metabolism responses to low-dietary magnesium are affected by dietary copper in postmenopausal women. Nutrition 2003; 19: 617-26. 
31. Nielsen FH, Milne DB, Gallagher S, Johnson L, Hoverson B. Moderate magnesium deprivation results in calcium retention and altered potassium and phosphorus excretion by postmenopausal women. Magnes Res 2007; 20: 19-31.

32. Nielsen FH, Milne DB, Klevay LM, Gallagher S, Johnson L. Dietary magnesium deficiency induces heart rhythm changes, impairs glucose tolerance, and decreases serum cholesterol in post menopausal women. J Am Coll Nutr 2007; 26: 121-32.

33. Paolisso G, Sgambato S, Gambardella A, Pizza G, Tesauro P, Varricchio M, D’Onofrio F. Daily magnesium supplements improve glucose handling in elderly subjects. Am J Clin Nutr 1992; 55: 1161-7.

34. Sacks FM, Willett WC, Smith A, Brown LE, Rosner B, Moore TJ. Effect on blood pressure of potassium, calcium, and magnesium in women with low habitual intake. Hypertension 1998; 31: 131-8.

35. Walker AF, De Souza MC, Marakis G, Robinson PA, Morris AP, Bolland KM. Unexpected benefit of sorbitol placebo in $\mathrm{Mg}$ intervention study of premenstrual symptoms: implications for choice of placebo in RCTs. Med Hypotheses 2002; 58: 213-20.

36. Walker AF, De Souza MC, Vickers MF, Abeyasekera S, Collins ML, Trinca LA. Magnesium supplementation alleviates premenstrual symptoms of fluid retention. J Womens Health 1998; 7: 1157-65.

37. Walker AF, Marakis G, Christie S, Byng M. Mg citrate found more bioavailable than other Mg preparations in a randomised, double-blind study. Magnes Res 2003; 16: 183-91.

38. Závaczki Z, Szöllosi J, Kiss SA, Koloszár S, Fejes I, Kovács L, Pál A. Magnesium-orotate supplementation for idiopathic infertile male patients: a randomized, placebo-controlled clinical pilot study. Magnes Res 2003; 16: 131-6.

39. Zorbas YG, Kakurin VJ, Afonin VB, Charapakhin KP, Denogradov SD. Magnesium supplements' effect on magnesium balance in athletes during prolonged restriction of muscular activity. Kidney Blood Press Res 1999; 22: 146-53.

40. Huijgen HJ, Sanders R, Cecco SA, Rehak NN, Sanders GT, Elin RJ. Serum ionized magnesium: comparison of results obtained with three ion-selective analyzers. Clin Chem Lab Med 1999; 37: 465-70.

41. Song Y, Ridker PM, Manson JE, Cook NR, Buring JE, Liu S. Magnesium intake, C-reactive protein, and the prevalence of metabolic syndrome in middle-aged and older U.S. women. Diabetes Care 2005; $28:$ 1438-44.

42. He K, Liu K, Daviglus ML, Morris SJ, Loria CM, Van Horn L, Jacobs Jr. DR, Savage PJ. Magnesium intake and incidence of metabolic syndrome among young adults. Circulation 2006; 113: 1675-82.

43. Ford ES, Li C, McGuire LC, Mokdad AH, Liu S. Intake of dietary magnesium and the prevalence of the metabolic syndrome among U.S. adults. Obesity (Silver Spring) 2007; 15: 1139-46.

44. King DE, Mainous 3rd. AG, Geesey ME, Ellis T. Magnesium intake and serum C-reactive protein levels in children. Magnes Res 2007; 20: 32-6.

45. Beydoun MA, Gary TL, Caballero BH, Lawrence RS, Cheskin LJ, Wang Y. Ethnic differences in dairy and related nutrient consumption among US adults and their association with obesity, central obesity, and the metabolic syndrome. Am J Clin Nutr 2008; 87: 1914-25.

46. McKeown NM, Jacques PF, Zhang XL, Juan W, Sahyoun NR. Dietary magnesium intake is related to metabolic syndrome in older Americans. Eur $J$ Nutr 2008; 47:210-6.

47. King DE. Inflammation and elevation of C-reactive protein: does magnesium play a key role?. Magnes Res 2009; 22: 57-9.

48. Chacko SA, Song Y, Nathan L, Tinker L, de Boer IH, Tylavsky F, Wallace R, Liu S. Relations of dietary magnesium intake to biomarkers of inflammation and endothelial dysfunction in an ethnically diverse cohort of postmenopausal women. Diabetes Care 2010; 33: 304-10.

49. Kao WH, Folsom AR, Nieto FJ, Mo JP, Watson RL, Brancati FL. Serum and dietary magnesium and the risk for type 2 diabetes mellitus: the atherosclerosis risk in communities study. Arch Intern Med 1999; 159: 2151-9.

50. Corica F, Corsonello A, Ientile R, Cucinotta D, Di Benedetto A, Perticone F, Dominguez LJ, Barbagallo M. Serum ionized magnesium levels in relation to metabolic syndrome in type 2 diabetic patients. $J$ Am Coll Nutr 2006; 25: 210-5.

51. Rayssiguier Y, Gueux E, Nowacki W, Rock E, Mazur A. High fructose consumption combined with low dietary magnesium intake may increase the incidence of the metabolic syndrome by inducing inflammation. Magnes Res 2006; 19: 237-43.

52. Belin RJ, He K. Magnesium physiology and pathogenic mechanisms that contribute to the development of the metabolic syndrome. Magnes Res 2007; 20: 107-29.

53. Simmons D, Joshi S, Shaw J. Hypomagnesaemia is associated with diabetes: not pre-diabetes, obesity or the metabolic syndrome. Diabetes Res Clin Pract 2010; 87: 261-6.

54. Lima Mde L, Cruz T, Rodrigues LE, Bomfim O, Melo J, Correia R, Porto M, Cedro A, Vicente E. 
Serum and intracellular magnesium deficiency in patients with metabolic syndrome-evidences for its relation to insulin resistance. Diabetes Res Clin Pract 2009; 83: 257-62.

55. Günther T. Biochemical mechanisms of the metabolic syndrome and the role of magnesium. Magnes Res 2010; 23: 142-5.

56. Rayssiguier Y, Libako P, Nowacki W, Rock E. Magnesium deficiency and metabolic syndrome: stress and inflammation may reflect calcium activation. Magnes Res 2010; 23: 73-80.

57. Guerrero-Romero F, Bermudez-Peña C, RodríguezMorán M. Severe hypomagnesemia and low-grade inflammation in metabolic syndrome. Magnes Res 2011; 24: 45-53.

58. Coudray C, Rambeau M, Feillet-Coudray C, Gueux E, Tressol JC, Mazur A, Rayssiguier Y. Study of magnesium bioavailability from ten organic and inorganic $\mathrm{Mg}$ salts in $\mathrm{Mg}$-depleted rats using a stable isotope approach. Magnes Res 2005; 18: 215-23.

59. Hunt CD, Johnson LK. Magnesium requirements: new estimations for men and women by crosssectional statistical analyses of metabolic magnesium balance data. Am J Clin Nutr 2006; 84: 843-52.

60. Hunter DJ, Lange M, Snieder H, MacGregor AJ, Swaminathan R, Thakker RV, Spector TD. Genetic contribution to renal function and electrolyte balance: a twin study. Clin Sci (Lond) 2002; 103: 259-65.

61. Henrotte JG, Pla M, Dausset J. HLA- and H-2associated variations of intra- and extracellular magnesium content. Proc Natl Acad Sci U S A 1990; 87: 1894-8.

62. Feillet-Coudray C, Coudray C, Wolf FI, Henrotte JG, Rayssiguier Y, Mazur A. Magnesium metabolism in mice selected for high and low erythrocyte magnesium levels. Metabolism 2004; 53:660-5.

63. Schmitz C, Deason F, Perraud AL. Molecular components of vertebrate $\mathrm{Mg} 2+$-homeostasis regulation. Magnes Res 2007; 20: 6-18.

64. Alexander RT, Hoenderop JG, Bindels RJ. Molecular determinants of magnesium homeostasis: insights from human disease. J Am Soc Nephrol 2008 ; 19 : $1451-8$.

65. Quamme GA. Molecular identification of ancient and modern mammalian magnesium transporters. Am J Physiol Cell Physiol 2010; 298: C407-29.

66. Meyer TE, Verwoert GC, Hwang SJ, Glazer NL, Smith AV, van Rooij FJ, Ehret GB, Boerwinkle E, Felix JF, Leak TS, Harris TB, Yang Q, Dehghan A, Aspelund T, Katz R, Homuth G, Kocher T, Rettig R, Ried JS, Gieger C, Prucha H, Pfeufer A, Meitinger T, Coresh J, Hofman A, Sarnak MJ, Chen YD, Uitterlinden AG, Chakravarti A, Psaty BM, van Duijn CM, Kao WH, Witteman JC, Gudnason V, Siscovick DS, Fox CS, Köttgen A, \& Genetic Factors for Osteoporosis Consortium; Meta Analysis of Glucose and Insulin Related Traits Consortium. Genome-wide association studies of serum magnesium, potassium, and sodium concentrations identify six loci influencing serum magnesium levels. PLoS Genet 2010;6: e1001045. 